\title{
Paronychia, CTCAE
}

National Cancer Institute

\section{Source}

National Cancer Institute. Paronychia, CT CAE. NCI Thesaurus. Code C143737.

A disorder characterized by an infectious process involving the soft tissues around the nail. 